\title{
Physicochemical Characterization of the Waters of the Sinú River, Downstream of the Urrá Reservoir, North of Colombia
}

\author{
Fernando Jove Wilches*1, Jhon Jairo Feria Díaz ${ }^{1}$ and José Hernández Ávila ${ }^{1}$ \\ ${ }^{1}$ Department of Civil Engineering, Universidad de Sucre, Sincelejo, Sucre, Colombia.
}

ORCIDs: 0000-0002-2080-4036 (Fernando), 0000-0003-1397-1546 (Jhon), 0000-0002-7557-9665 (Jose)

\begin{abstract}
The essential objective of any engineering project should be aimed at providing solutions that allow the well-being and improvement of the living conditions of the inhabitants of the project area, in such a way that the interventions carried out are environmentally friendly and allow the sustainability of natural resources over time. Many of these projects, due to the impact they generate, must be periodically monitored to accurately verify the positive or negative changes that they may have generated after their construction.

One type of project of great interest due to its high impact on the environment and on people is dams or reservoirs, which significantly change the environmental conditions upstream and downstream of the waterways in which they are located. The changes can be so significant that they could devastate rivers, threaten the survival of surrounding fauna and flora, destroy surrounding valleys, flood large areas of wetlands, forests and agricultural lands, displace populations or leave many of them in imminent danger, before a possible collapse of the structure. The purpose of this document is to present a database that contains variables directly related to the effects produced by the installation of the Urrá reservoir, located in the channel of the Sinú river, in the north of Colombia. The information corresponds to historical data from seven consecutive years of follow-up, from 2008 to 2014. It includes the following physicochemical parameters: Biochemical Oxygen Demand (BOD5), Dissolved Oxygen (DO), Temperature and $\mathrm{pH}$, taken in seven stations located along the channel of the river Sinú. The data set helps to perform simulations to determine the quality of the water flowing through the river and to verify whether the reservoir project has had an influence on the pollution of the stream. In a complementary way, these data help to understand the biological interaction that is generated between the organisms that inhabit the area and determine if the environment has been altered.
\end{abstract}

Keywords: Biochemical Oxygen Demand (BOD 5 ), Dissolved Oxygen (DO), Water Quality, Sinú River, Urrá I Reservoir.

\section{INTRODUCTION}

Water is a vital resource for life on the planet, it acts as a fundamental element for a number of physical, chemical and biological processes, which makes today's world possible. In the case of Colombia, this is one of the richest countries in water resources in the world, it is located in the seventh position, after China with an availability of $2,132 \mathrm{~km}^{3} /$ year [1].

Water resources, being so important in the life of all living beings on the planet, must be properly preserved. However, unfortunately, every year the water systems are more polluted and the quality of the water is affected. According to studies carried out in recent times, the availability and quality of water, in its liquid form and found in a superficial or underground way, has had a deterioration due to factors related to the interaction of human beings with the environment, such as population growth, industrialization and urbanization [2].

For the management of water resources, periodic monitoring of bodies of water is essential. This activity makes it possible to detect changes in the quality of the resource at an early age, which makes it a very useful tool for its protection [3].

The quality of the water is evaluated and classified based on the degree of purity and contamination present in it, and it is evaluated from the physical, chemical and biological characteristics [4].

This activity can become somewhat complex, because the water resource is exposed to a great variety of factors and parameters that are directly related to the quality of the water. Among the methodologies that help to characterize the physicochemical properties of the water resource, there is the determination of the Biochemical Oxygen Demand (BOD5) and the Dissolved Oxygen (DO) that is present in the water. These parameters provide information about the concentration of organic matter, and measure the amount of oxygen used by microorganisms in the stabilization of biodegradable organic matter, under aerobic conditions [5].

Under normal laboratory conditions, BOD is determined at a temperature of $20^{\circ} \mathrm{C}$ in a time of 5 days, being expressed in $\mathrm{mg} / 1 \mathrm{O} 2$ and is known as BOD5. This procedure was adopted in 1936 by the American Public Health Association, and since then, it has remained an indicator of contamination [6].

The objective of this document is to show some of the physicochemical parameters of the waters of the Sinú River, downstream of the Urra I dam reservoir, located in the department of Córdoba, north of Colombia. The information analyzed corresponds to the Biochemical Oxygen Demand (BOD5), Dissolved Oxygen (DO), Temperature and $\mathrm{pH}$. These values were measured at seven stations located along the Sinú riverbed. This allowed the construction of graphs that contribute to the analysis of the quality of the water that runs 
International Journal of Engineering Research and Technology. ISSN 0974-3154, Volume 13, Number 10 (2020), pp. 2909-2914

(C) International Research Publication House. https://dx.doi.org/10.37624/IJERT/13.10.2020.2909-2914

through said tributary, makes it possible to know its current conditions and helps to determine the impact that the location of the Urra I reservoir has had on the contamination of the stream.

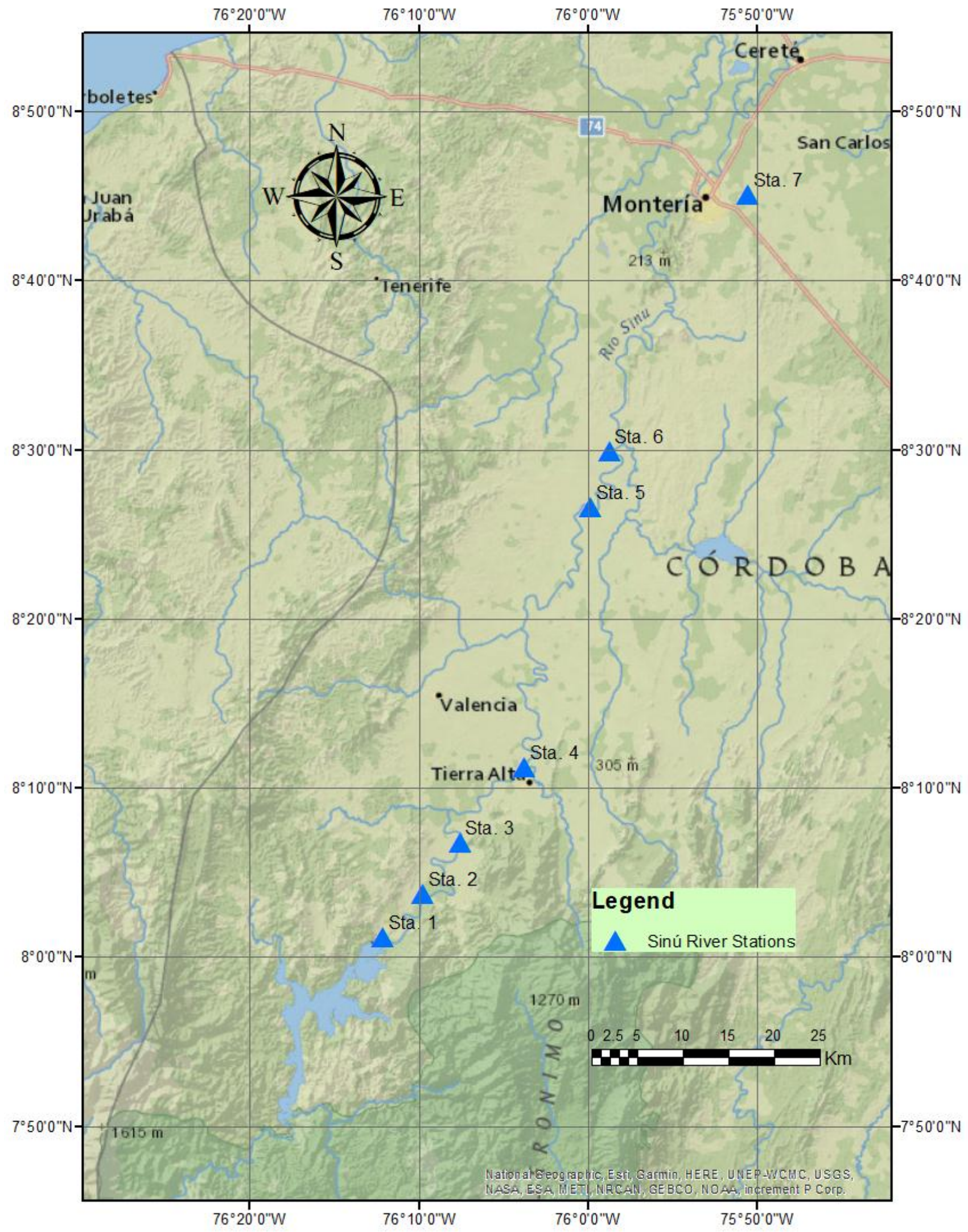

Fig 1. Coordinates of the monitoring stations on the Sinú River. 


\section{EXPERIMENTAL DESIGN, MATERIALS AND METHODS}

\section{II.I Study area description}

The Sinú River runs in a south-north direction from its source in the Paramillo Nudo in the municipality of Ituango, department of Antioquia, at 3,500 meters above sea level, between the foothills of the Serranías de Abibe and San Jerónimo, south of the department of Córdoba. It empties directly into the Tinajones delta area through three mouths called Mireya, Medio and Corea located in the municipality of San Bernardo del Viento at the southern end of the Gulf of Morrosquillo (Caribbean Sea). It is approximately $380 \mathrm{~km}$ long, with a basin area of $13,700 \mathrm{~km}^{2}$, of which $1,100 \mathrm{~km}^{2}$ correspond to the Department of Antioquia and the remaining $12,600 \mathrm{~km}^{2}$ to the Department of Córdoba. Throughout its course it establishes complex interactions with streams and streams that contribute to its waters and with swamps and flooded areas, which capture their excesses in the winter period [7], [8].

\section{II.II Material and methods}

The current of the Sinú River was divided into two sections: Upper and Middle. Seven monitoring stations were characterized (Fig. 1), located from the Urrá I reservoir to the city of Montería, Colombia. The stations were located at strategic points with easy access and close to populated areas.

The samples taken were punctual and were taken in the field, the $\mathrm{pH}$ and temperature parameters in the laboratory, the values of dissolved Oxygen and Biochemical Oxygen Demand, following the measurement protocols established in the Standard Methods for the Analysis of Drinking and Residual Waters according to the American Public Health Association [9]. The specific samples were refrigerated at $4{ }^{\circ} \mathrm{C}$ and transported to the facilities of the water quality laboratory of the Universidad Pontificia Bolivariana, in the city of Montería, Colombia, where they were processed.

Table 1. Coordinates of the monitoring stations on the Sinú River

\begin{tabular}{llccc}
\hline Station & \multicolumn{1}{c}{ Station Name } & $\begin{array}{c}\text { Distance to the Reservoir } \\
(\mathbf{K m})\end{array}$ & Latitude & Longitude \\
\hline Station 1 & Angostura & 0.96 & $8^{\circ} 01^{\prime} 10.9^{\prime \prime}$ & $-76^{\circ} 12^{\prime} 8.7^{\prime \prime}$ \\
Station 2 & Pasacaballos & 11.0 & $8^{\circ} 03^{\prime} 42.8^{\prime \prime}$ & $-76^{\circ} 09^{\prime} 45.3^{\prime \prime}$ \\
Station 3 & El Toro & 38.0 & $8^{\circ} 06^{\prime} 47.7^{\prime \prime}$ & $-76^{\circ} 07^{\prime} 34.7^{\prime \prime}$ \\
Station 4 & Tierralta & 46.6 & $8^{\circ} 11^{\prime} 13.8^{\prime \prime}$ & $-76^{\circ} 03^{\prime} 46.4^{\prime \prime}$ \\
Station 5 & Las Palomas & 97.8 & $8^{\circ} 26^{\prime} 37.8^{\prime \prime}$ & $-75^{\circ} 59^{\prime} 52.7^{\prime \prime}$ \\
Station 6 & Nueva Colombia & 112.0 & $8^{\circ} 29^{\prime} 56.4^{\prime \prime}$ & $-75^{\circ} 58^{\prime} 44.9^{\prime \prime}$ \\
Station 7 & Montería & 163.0 & $8^{\circ} 45^{\prime} 6.5^{\prime \prime}$ & $-75^{\circ} 50^{\prime} 33.1^{\prime \prime}$ \\
\hline
\end{tabular}

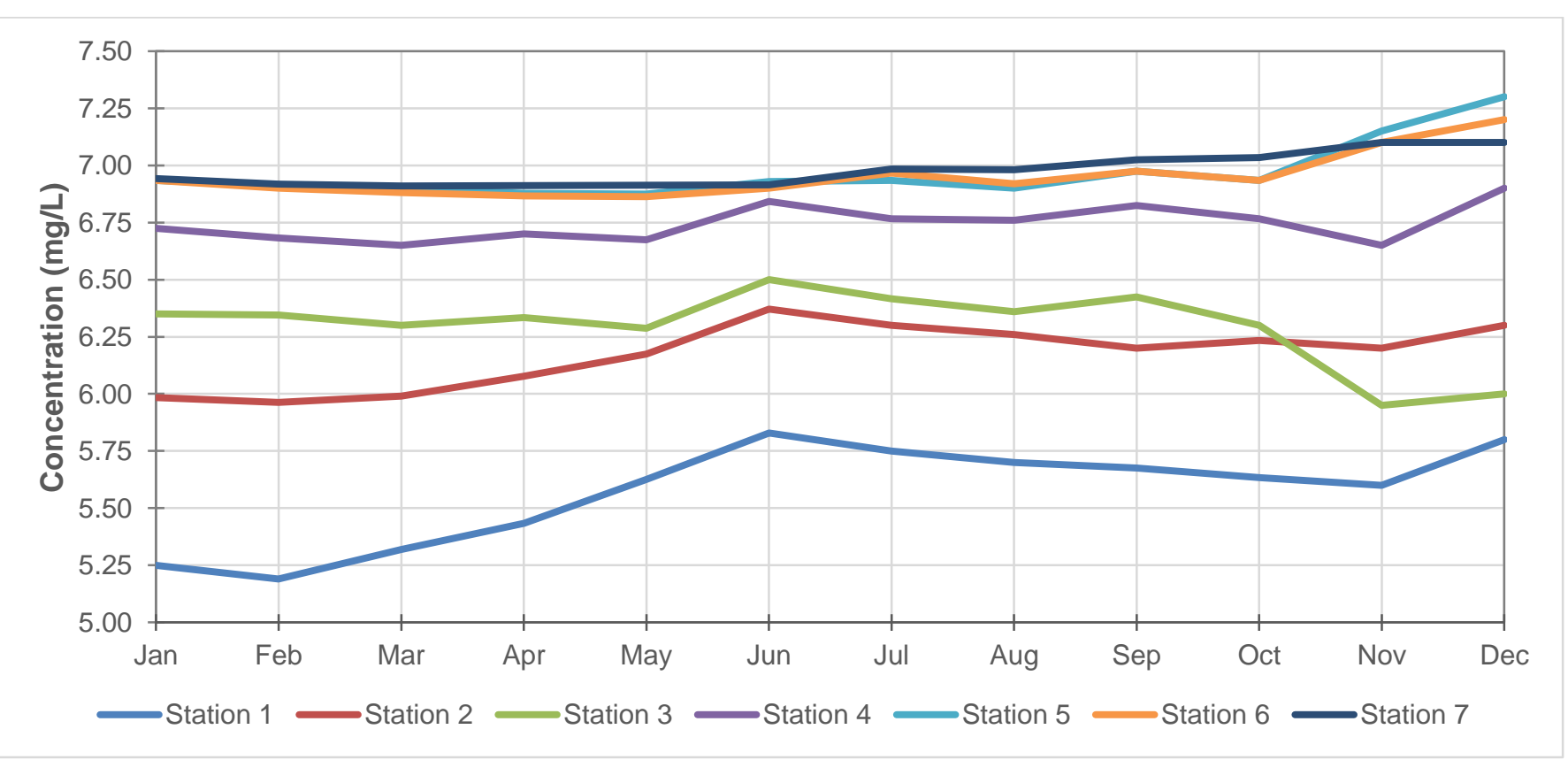

Fig. 2. Monthly average Dissolved Oxygen values at each sampling station during the recording years 


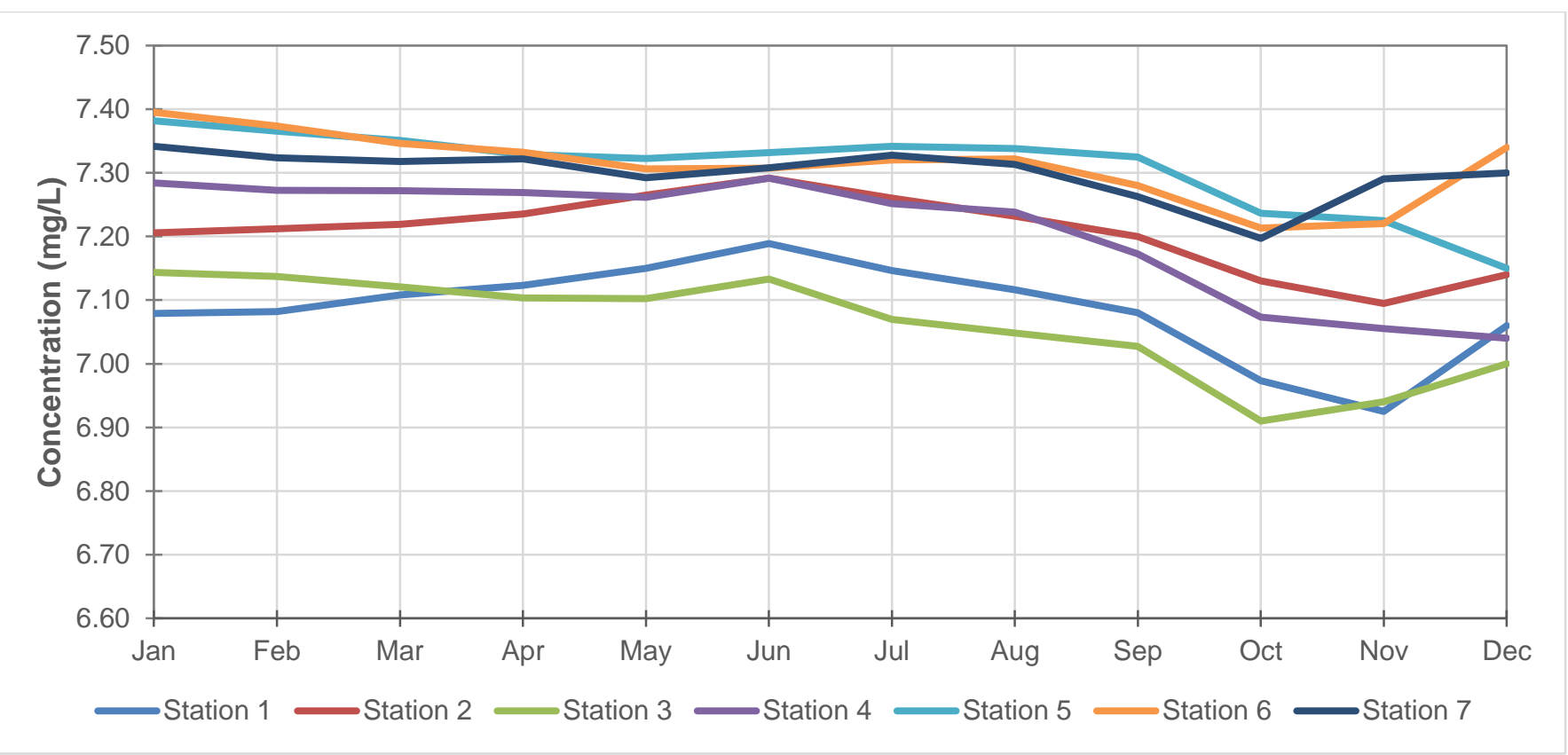

Fig. 3. Monthly average $\mathrm{pH}$ values at each sampling station during the recording years

\section{RESULTS}

Sinú River, which were obtained and analyzed based on the data collected from seven monitoring stations located at different sites downstream of the Sinú River channel, Córdoba (Colombia). This section will show the data collected and processed on the characteristics of the water in the mentioned area.

Fig. 1 shows the location of the research area and the location of the seven sampling stations. Table 1 shows the coordinates and distances downstream of the reservoir from the sampling stations. Fig. 2 shows the monthly average values of Dissolved Oxygen, for each station under study, obtained from all the years monitored. In Fig. 3 the monthly average $\mathrm{pH}$ values are shown, for each station under study, obtained from all the monitored years. The monthly average values of Dissolved Oxygen, $\mathrm{pH}$ and temperature are presented in Fig. 4; in which the values obtained from all the stations and all the monitored years have been considered. In Fig. 5 the Annual Average Biological Demand for Oxygen, Dissolved Oxygen and $\mathrm{pH}$ are presented for each monitoring station.

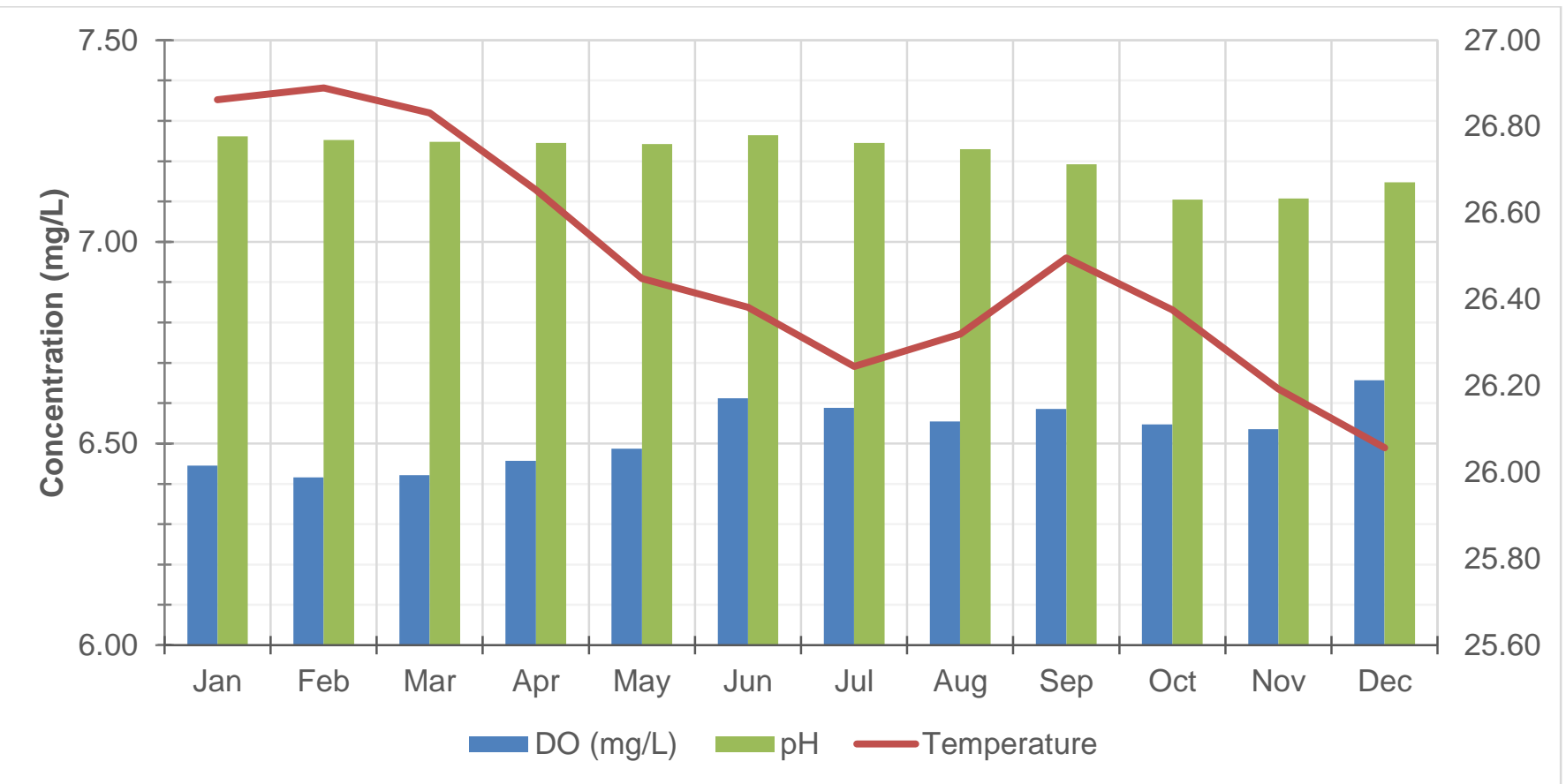

Fig. 4. Monthly average Dissolved Oxygen and $\mathrm{pH}$ values 


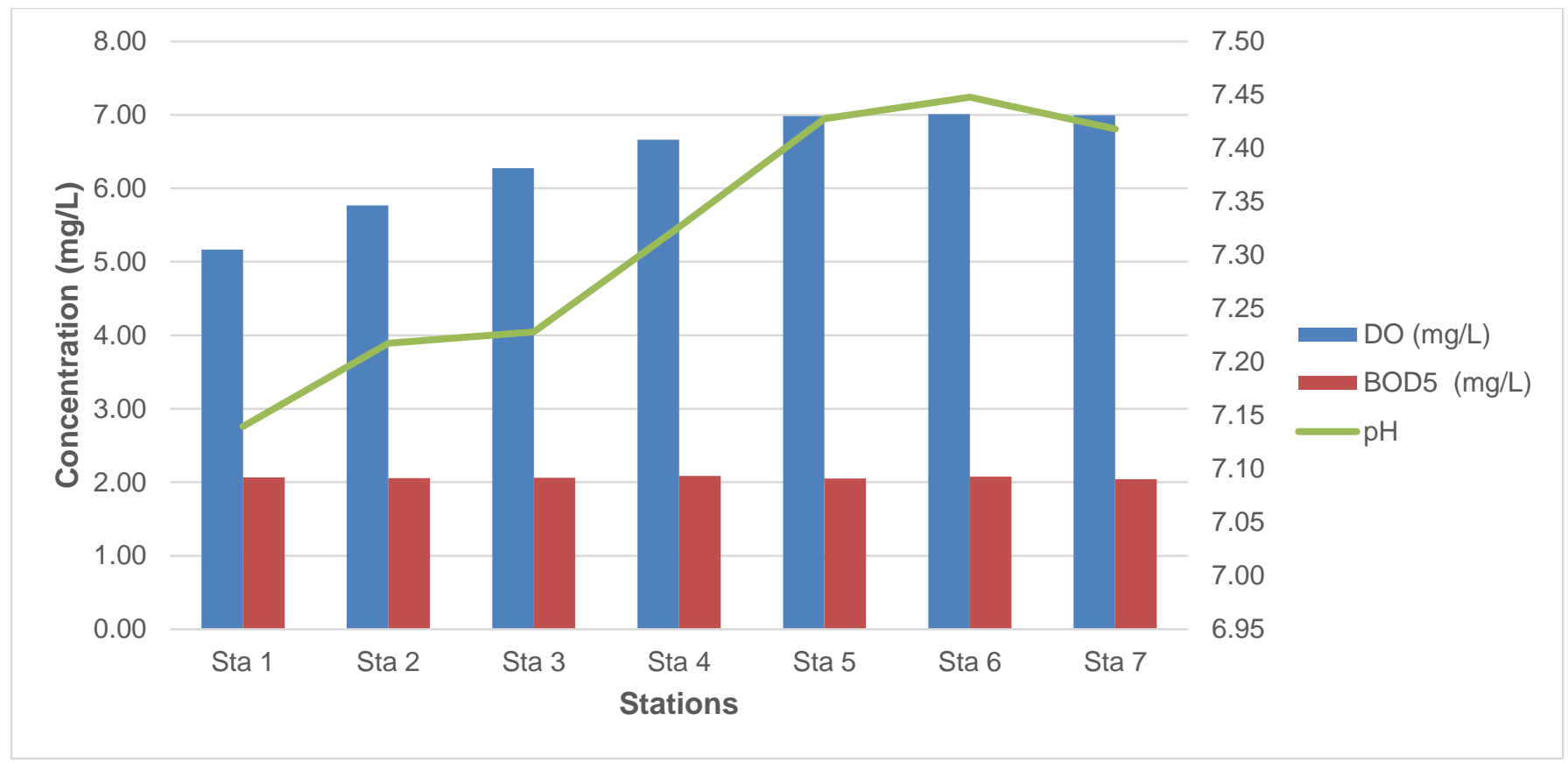

Fig. 5. Average annual values of Biological Demand for Oxygen, Dissolved Oxygen and pH

\section{CONCLUSIONS}

According to the results obtained, it was possible to establish that the water temperature of the Sinú River varies through the months, in accordance with the rainy and dry seasons that occur in the region, with the highest temperatures being those of the months at the beginning of the year and the lowest, in the middle and end. Regarding the $\mathrm{pH}$ concentration, this is quite constant throughout the year, with only slight reductions in its values in the final of the year, but presenting mean values throughout the year between 7.10 and 7.26. Regarding the Oxygen Demand, an increase is noted in the second semester of the year, presenting the highest values in June and December.

Performing the analysis for the sampling stations, there is a clear relationship between the distances of the station with respect to the Urra I reservoir in relation to the measured value, for the properties of Dissolved Oxygen and $\mathrm{pH}$. In both cases, for the sampling stations furthest from the reservoir, higher values were presented. In the case of the BOD5 Oxygen Demand, there were very similar values throughout the period and throughout the seasons, around $2 \mathrm{mg} / \mathrm{L}$. It is also worth emphasizing that the values read are within the range of admissible values stipulated by the competent authorities.

\section{Acknowledgments}

The authors thank Empresa Urrá S.A. E.S.P. and to the Universidad Pontificia Bolivariana, Sede Montería, for the authorized supply of the database of the physicochemical parameters of the Sinú River water, within the framework of the monitoring of the environmental license granted for the operation of the Urrá I hydroelectric plant. Authors also thank the engineer Edilberto Elias Contreras Sierra for the contributions made in the development of the manuscript.

\section{REFERENCES}

[1] Gualdrón L. Evaluación de la calidad de agua de ríos de colombia usando parámetros físicoquímicos y biológicos, Dinamica Ambiental. 2006; (1) 1: 83-101. DOI: https://doi.org/10.18041/25906704/ambiental.1.2016.4593

[2] Tyagi S, Sharma B, Singh P, Dobhal R. Water Quality Assessment in Terms of Water Quality Index, American Journal of Water Resources. 2013; 1(3): 34-38. DOI: http://doi.org/10.12691/ajwr-1-3-3

[3] Castro M, Almeida J, Ferrer J, Díaz D. Indicadores de la calidad del agua: evolución y tendencias a nivel global, Ingeniería Solidaria. 2014; 10(17). DOI: http://dx.doi.org/10.16925/in.v9i17.811

[4] Pérez J, Nardini A, Galindo A. Análisis Comparativo de Índices de Calidad del Agua Aplicados al Río Ranchería, La Guajira-Colombia. Información tecnológica. 2018; 29(3): 47-58. DOI: https://dx.doi.org/10.4067/S0718$\underline{07642018000300047}$

[5] Instituto de Hidrología, Meteorología y Estudios Ambientales, Demanda Bioquìmica de Oxìgeno 5 días, incubaciòn y electrometría, Ministerio de Ambiente, Vivienda y Desarrollo Territorial, Colombia, 2007.

[6] Raffo E, Ruiz E. Caracterización de las aguas residuales y la demanda bioquímica de oxígeno. Industrial Data. 2014; 17(1):71-80. . Recuperado de https://www.redalyc.org/pdf/816/81640855010.pdf

[7] Instituto Colombiano de Geología y Minería INGEOMINAS, Mapa Hidrogeológico de Córdoba. http://recordcenter.sgc.gov.co/B3/12006025002784/docu 
International Journal of Engineering Research and Technology. ISSN 0974-3154, Volume 13, Number 10 (2020), pp. $2909-2914$

(C) International Research Publication House. https://dx.doi.org/10.37624/IJERT/13.10.2020.2909-2914

mento/pdf/0101027841101000.pdf, 2004 (accessed 1

August 2020).

[8] Corporación Autónoma Regional de los Valles del Sinú y del San Jorge - CVS, Plan de Acción para la Temporada Invernal en el Departamento de Córdoba - PATI CVS. https://www.cvs.gov.co/jupgrade/images/stories/docs/pla nes/PLAN\%20DE\%20ACCION\%20T INVERNAL V8 2014.pdf, 2014 (accessed 1 August 2020).

[9] American Public Health Association - APHA, Standard Methods for Examination of Water and Wastewater, 21 ed., APHA, Washington D.C., 2005. 